\title{
A Comparative Study on the Effect of Leptin Hormone and Gemfibrozil in an Experimental Model of Hyperlipidemia Induced by Chronic Ethanol Treatment
}

\author{
Heba Taha ${ }^{1}$, El-Sharkawi $F^{1}$ and Samy A. Abd El-Azim ${ }^{2}$ \\ ${ }^{1}$ Biochemistry Department, Faculty of Pharmacy, Helwan University \\ ${ }^{2}$ Biochemistry Department, Faculty of Pharmacy, Cairo University
}

\begin{abstract}
The aim of the present study was to evaluate the effect of leptin hormone and Gemfibrozil on the body weight, hepatic \& serum lipids and lipoproteins profile in ethanol-induced hyperlipidemia in rats. The study was carried on 53 male albino rats weighing 130-160 g classified into six groups (from A-F). Three of these groups were fed a normal diet ( $A, C$ and $D)$, while the other groups ( $B, E$ and $F$ ) were fed a normal diet combined with ethanol ( $6.32 \mathrm{~g} / \mathrm{kg}$ body weight per oral) for the first 30 days. Subsequently, the first three groups received a normal diet for group (A), in addition to Gemfibrozil (100 mg/kg per oral daily) for group (C) or exogenous leptin (230 $\mu \mathrm{g} / \mathrm{kg}$ body weight, i.p.) every alternate day for group (D), while Groups (E) and (F) were administered Gemfibrozil and leptin respectively for the next 15 days. At the end of the total experimental period of 45 days, liver total lipids, serum concentrations of total cholesterol, HDL-C, LDL-C, VLDL-C, triglycerides, total proteins, albumin and glucose were measured. Ethanol-induced hyperlipidemia in rats resulted in marked increase of liver total lipids and significant increase of serum total cholesterol, $L D L-C, V L D L-C$ and triglycerides levels. This was associated with concomitant decrease in serum HDL-cholesterol and glucose levels as well as serum total proteins and albumin levels. However, no changes were observed in the body weight gain. Administration of leptin or Gemfibrozil separately or after ethanolinduced hyperlipidemia to rats was able to antagonize the ethanol-induced biochemical changes in the tissues studied. The results of the current study showed that leptin administered alone to rats resulted in marked decrease of their body weight and fasting serum glucose levels while serum HDL-C was elevated. These findings indicated that the chronic administration of exogenous leptin was more effective as compared to Gemfibrozil in preventing the rise in lipids and lipoproteins concentration in an animal model of alcohol-induced hyperlipidemia.
\end{abstract}

Keywords: Alcohol, Leptin, Gemfibrozil, Hyperlipidemia, Lipoproteins, Proteins.

\section{INTRODUCTION}

Leptin is a circulating hormone $(16 \mathrm{kDa})$ produced and released primarily by adipocytes, it exerts a regulatory control on food intake and energy expenditure ${ }^{(1)}$. Plasma leptin concentrations are correlated with total fat mass, percent body fat and body mass index (BMI). Leptin acts as a sensing hormone or 'lipostat' in a negative feedback control from 
adipose tissue to the hypothalamus ${ }^{(2)}$. Thus, leptin informs the brain about the abundance of body fat, thereby allowing feeding behavior, metabolism and endocrine physiology to be coupled to the nutritional state of the organism.

Fibrates constitute a well known group of hypolipidemic drugs which are used in treatment of mixed hyperlipoproteinemia and hypertriglyceridemia $^{(3)}$.

Gemfibrozil (GFZ) is a lipid regulating agent belonging to fibrates (4). It was introduced in the $1980 \mathrm{~s}$, and was, also, supported by the published results of the Helsinki heart Study which showed a significant reduction in coronary heart disease (CHD) events and an acceptable safety profile $^{(5)}$.

GFZ lowers plasma triglycerides and elevates HDL-C level in hypertriglyceridemic patients ${ }^{(6)}$.

Ethanol is a powerful inducer of hyperlipidemia in both animals and humans ${ }^{(7)}$. Also ethanol causes changes in the metabolism of lipoproteins ${ }^{(8)}$. Chronic alcohol intake is known to produce hypercholesterolemia, hyperlipidemia and hyper-triglyceridemia ${ }^{(9,10)}$.

The aim of the present study was to evaluate the chronic effects of exogenous administration of recombinant leptin and GFZ in rats on serum, tissue lipids and lipoproteins in an animal model of alcohol-induced hyper -lipidemia.

\section{MATERIAL \& METHODS}

\section{1-Material:}

All chemicals used were of high analytical grade, products of Sigma
(USA) and El-Nasr Chemical Industries Company. Rat Recombinant Leptin Hormone was imported from Sigma (St.Louis USA) and Gemfibrozil (Parke -Davis USA) was from Alcan Pharma.

\section{2-Animals and treatment:}

In the present study, 53 male albino rats weighed 130-160 g, were classified into six groups (from $\mathrm{A} \rightarrow \mathrm{F}$ ). Each group was composed of 8-10 rats and received normal diet during the total experimental period.

The first group (A) served as a normal control group receiving normal diet during the total experimental period of 45 days. While groups (C) and (D) received normal diet for 30 days. Liver cell damage was induced in rats of groups (B), (E) and $(\mathrm{F})$ by administering $16 \%$ ethanol ( $6.32 \mathrm{~g} / \mathrm{Kg}$ body weight) for 30 days. The groups were treated as follows for the next 15 days:

Groups (C) and (E) were administered Gemfibrozil (GFZ) (100 mg/Kg body weight per oral every day).

Groups (D) and (F) were administered exogenous leptin hormone (230 $\mu \mathrm{g} / \mathrm{Kg}$ body weight i.p. every alternate day).

3-Biochemical analysis:

Animals were fasted overnight and the blood samples were withdrawn from retro-orbital sinus of all animals of different groups at the end of the experiment (total period of 45 days). Serum samples were separated and stored frozen $-80^{\circ} \mathrm{C}$ until the following biochemical parameters were estimated: total cholesterol according to the enzymatic-colorimetric, Trinder, end point method as described by ${ }^{(\mathbf{1 1}, \mathbf{1 2})}$, triglycerides according to the 
enzymatic- colorimetric, end point method as described by ${ }^{(\mathbf{1 2 , 1 3})}$, low density lipoproteins (LDL-C) according to the precipitation, heparin/citrate method as described by $(14,15,16,17)$, high density lipoproteins (HDL-C) according to the precipitation, phosphotungestic acid method as described by $(\mathbf{1 8 , 1 9 , 2 0 )}$,very low density lipoproteins (VLDL), total proteins according to the biuret reaction, End point method as described by ${ }^{(12,21,22,23)}$, albumin according to the colorimetric bromocresol green (BCG) $\operatorname{method}^{(\mathbf{1 2 , 2 3 , 2 4 , 2 5 , 2 6 )} \text { and glucose }}$ according to the enzymaticcolorimetric, end point method as described by $(12,27,28,29,30)$.

At the end of the experiment (total period of 45 days), liver of all animals was separated after sacrification and divided into two parts, the first for determination of total lipids according to the sulpho phosphovanilline method as described by ${ }^{(31)}$ and the other for histopathological examination which was done as follows:

Liver slices (1 $\mathrm{mm}$ X $1 \mathrm{~mm}$ ) were fixated in glutaraldehyde over night. Ultra thin sections of the liver were processed as blocks of pure resin following the standard micro technique and evaluated for histopathological changes under an electron microscope.

\section{4- Statistical analysis:}

Statistical analysis of the data was performed using ordinary one way analysis of variance (ANOVA) for parametric data followed by TukeyKramer multiple comparisons test or ANOVA for non-parametric data followed by Dunn's test ${ }^{(32)}$.

\section{RESULTS}

\section{1- Body weight gain:}

The body weight of ethanoltreated group showed a significant reduction as compared to normal control group. Gemfibrozil (GFZ) treatment to rats alone didn't show any change in their body weights when compared to normal controls.

In contrast, the GFZ treatment to ethanol-treated rats resulted in significant reduction of body weights of rats when compared with either normal controls or GFZ group. Leptin administration alone to rats showed a significant reduction in the body weights of rats as compared to normal controls, while, administration of leptin to ethanol-treated rats didn't show any significant differences from the leptin administered group [Table (1) and fig $(1,2)]$.

\section{2- Liver total lipids, serum TG and VLDL-C:}

Table (2) and fig (3) shows that liver total lipids level was markedly increased in ethanol-treated group as compared to normal control group.

Administration of either GFZ or leptin alone to rats showed insignificant decrease in the liver total lipids level of rats as compared to normal control group, while they showed a marked reduction in liver total lipids as compared to ethanoltreated rats. On the other hand, administration of either GFZ or leptin to ethanol-treated rats showed a significant reduction in the liver total lipids as compared to ethanol-treated rats but still the values were higher than the normal control group. 
The serum TG and VLDL-C levels of ethanol-treated group were significantly increased when compared to normal controls. Administration of either GFZ or leptin alone to normal rats didn't show any changes in their serum levels of TG and VLDL-C from the control values.

In contrast, administration of either GFZ or leptin to ethanol-trated rats produced marked reduction in serum TG and VLDL-C levels as compared to ethanol-treated rats.

3- Serum total cholesterol (TC), LDL-C, HDL-C and LDL/HDL ratio:

The serum levels of TC, LDL-C and LDL-C/HDL-C ratio were significantly elevated, while the serum level of HDL-C was significantly decreased in ethanol-treated group as compared to normal control group as given in table (3) and fig (4).

Administration of either GFZ or leptin alone to rats didn't change the level of serum studied parameters.

However, administration of GFZ or leptin to ethanol-treated groups resulted in significant reduction of the elevated serum level of TC, LDL-C and LDL/HDL ratio, while, the serum level of HDL-C was elevated.

\section{4- Serum total proteins, albumin and} A/G ratio:

Table (4) and fig (5) revealed that the serum albumin level of ethanoltreated group was significantly reduced as compared to normal controls, while the change in serum levels of total protein and $\mathrm{A} / \mathrm{G}$ ratio of ethanol-treated group was insignificant from the normal control values.

On the other hand, administration of either GFZ or leptin alone to rats didn't show any significant difference in the serum level of total protein, albumin and $\mathrm{A} / \mathrm{G}$ ratio as compared to normal controls.

However, administration of either GFZ or leptin to ethanol-treated rats resulted in normalization of the serum levels of total proteins, albumin and $\mathrm{A} / \mathrm{G}$ ratio.

\section{5- Serum glucose level:}

As shown in table (5) and fig (6), the serum glucose level of all groups didn't show any significant changes when compared to normal controls.

In contrast, leptin group showed a significant reduction in the serum glucose level when compared with either normal controls or ethanoltreated group.

\section{6- Histopathological examination of liver tissues:}

Fig (7) showed that in control rats the liver cells appeared with normal nature of cell organelles (fig 7a). While the liver cells of ethanol treated rats appeared unhealthy with slight congestion and fatty degeneration in portal canals (fig 7b).

Liver cells treated with GFZ were slightly improved with nearly normal nuclei and slight dilatation in endoplasmic reticulum (fig 7c). While leptin treated liver cells appeared normal with normal arrangement of plates and normal cell organelles (fig 7d). 
Table (1): The effect of ethanol, GFZ, leptin hormone or combination of ethanol with either GFZ or leptin hormone on weight of animals (Mean \pm S.E):

\begin{tabular}{|l|c|c|c|c|c|c|}
\hline \multicolumn{1}{|c|}{ Group } & $\begin{array}{c}\text { Control } \\
\text { Group } \\
\text { Parameter }\end{array}$ & $\begin{array}{c}\text { Ethanol } \\
\text { Group } \\
\text { (A) }\end{array}$ & $\begin{array}{c}\text { GFZ } \\
\text { Group } \\
\text { (C) }\end{array}$ & $\begin{array}{c}\text { Leptin } \\
\text { Group } \\
\text { (D) }\end{array}$ & $\begin{array}{c}\text { Eth+GFZ } \\
\text { Group } \\
\text { (E) }\end{array}$ & $\begin{array}{c}\text { Eth+Leptin } \\
\text { Group } \\
\text { (F) }\end{array}$ \\
\hline $\begin{array}{l}\text { Mean weight (g) of } \\
\text { the animals at the }\end{array}$ & $\begin{array}{c}143.62 \pm \\
\text { start. }\end{array}$ & $\begin{array}{c}141.20 \pm \\
3.94\end{array}$ & $146 \pm 3.55$ & $147.50 \pm 3$ & $145.2 \pm$ & $150.13 \pm$ \\
& & & & 3.46 & 2.75 \\
Mean weight (g) of & $* * *$ & $*$ & & $* *$ & $*$ & $* *$ \\
the animals at the end. & $165.62 \pm$ & $124.70 \pm$ & $158.40 \pm$ & $128.88 \pm$ & $112.20 \pm$ & $132.63 \pm$ \\
& 4.14 & 4.74 & 6.66 & 4.06 & 12.41 & 4.26 \\
\hline Weight (g) gain & & $\mathrm{xxx}$ & aaa & $\mathrm{xxx}$ & $\mathrm{Xxx}$ & $\mathrm{xxx}$ \\
during the experiment & $22 \pm 1.19$ & -16.50 & 12.40 & $-18.62 \pm$ & $-33 \pm$ & $-17.50 \pm$ \\
& & \pm 1.65 & \pm 3.11 & 1.06 & 8.95 & 1.51 \\
\end{tabular}

$\mathrm{x}, \mathrm{xx}$ and $\mathrm{xxx}$ : Significantly different from normal control group at $\mathrm{x}=\mathrm{P}<0.05, \mathrm{xx}=$ $\mathrm{P}<0.01$ and $\mathrm{xxx}=\mathrm{P}<0.001$.

(aaa): Significantly different from (Ethanol +Leptin) group at $\mathrm{P}=<0.001$.

(bbb) Significantly different from (Leptin) group at $\mathrm{P}=<0.001$

(ccc): significantly different from (GFZ) group at $\mathrm{P}=<0.001$.

$*, * *$ and $* * *$ : Significantly different from the corresponding group at initial weight at

$*=\mathrm{P}<0.05, * *=\mathrm{P}<0.01$ and $* * * \mathrm{P}<0.001$. 


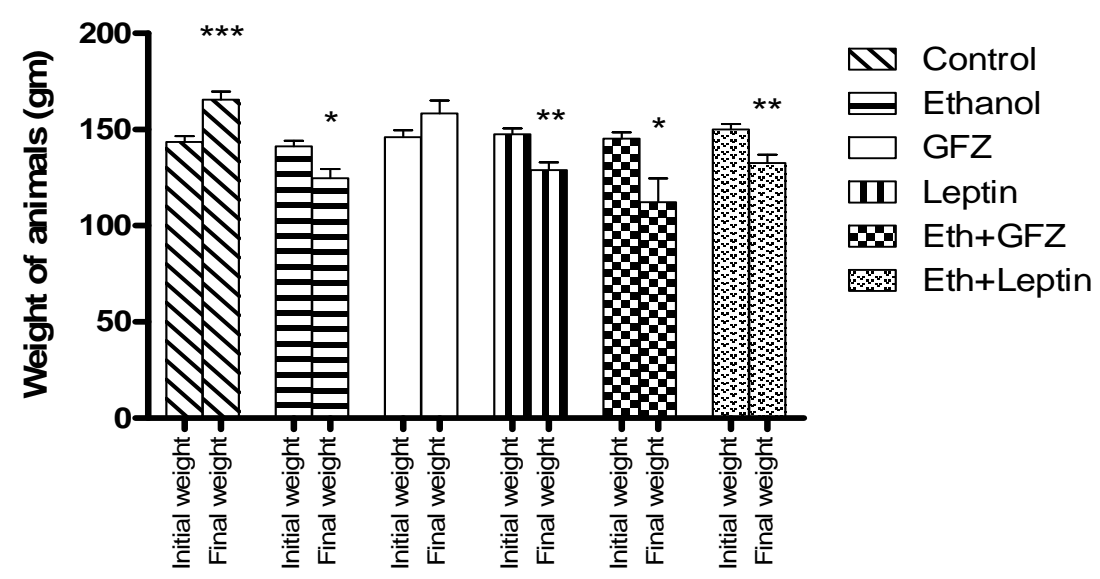

Fig (1): Initial and final body weight of control and experimental rats administered with ethanol, GFZ, leptin, Ethanol+ GFZ and ethanol+ leptin for 45 days.

\section{Body Weight Gain}

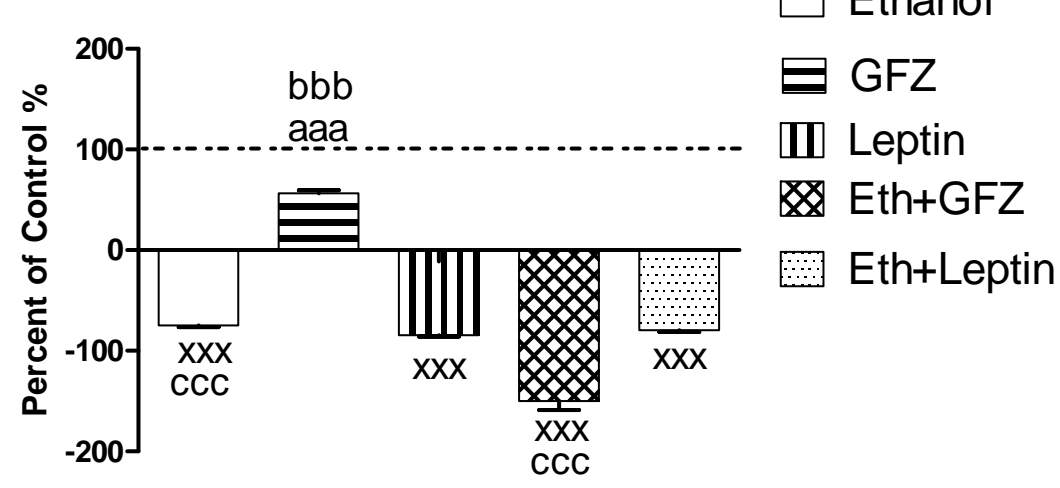

Fig (2): Weight gain of control and experimental rats administered with ethanol, GFZ, leptin, Ethanol+ GFZ and ethanol+ leptin for 45 days. 
Table (2): The effect of ethanol, GFZ, leptin hormone or combination of ethanol with either GFZ or leptin hormone on liver tissue total lipids, serum triglycerides and serum VLDL-C (Mean \pm S.E):

\begin{tabular}{|c|c|c|c|c|c|c|}
\hline Parameter & $\begin{array}{l}\text { Control } \\
\text { Group } \\
\text { (A) }\end{array}$ & $\begin{array}{l}\text { Ethanol } \\
\text { Group } \\
\text { (B) }\end{array}$ & $\begin{array}{l}\text { GFZ } \\
\text { Group } \\
\text { (C) }\end{array}$ & $\begin{array}{l}\text { Leptin } \\
\text { Group } \\
\text { (D) }\end{array}$ & $\begin{array}{c}\text { Eth+GFZ } \\
\text { Group } \\
\text { (E) }\end{array}$ & $\begin{array}{c}\text { Eth+Lepti } \\
\text { n Group } \\
(\mathrm{F})\end{array}$ \\
\hline $\begin{array}{l}\text { Total Lipids in } \\
\text { liver } \\
\text { tissue }(\mathrm{mg} / \mathrm{dl})\end{array}$ & $\begin{array}{c}608.33 \pm \\
60.98\end{array}$ & $\begin{array}{c}1336.68 \pm \\
111.05 \\
x x\end{array}$ & $\begin{array}{c}* * * \\
476.67 \pm \\
23.85 \\
\text { (aa) }\end{array}$ & $\begin{array}{c}* \\
645.92 \pm \\
33.05\end{array}$ & $\begin{array}{c}* \\
766.70 \pm \\
135.28\end{array}$ & $\begin{array}{c}* \\
1015.86 \\
\pm 46.05\end{array}$ \\
\hline $\begin{array}{l}\text { Serum } \\
\text { Triglycerides } \\
(\mathrm{mg} / \mathrm{dl})\end{array}$ & $\begin{array}{c}27.52 \pm \\
3.05\end{array}$ & $\begin{array}{l}129 \pm \\
3.16 \\
x x x\end{array}$ & $\begin{array}{c}* * * \\
27.73 \pm \\
3.02\end{array}$ & $\begin{array}{c}* * \\
31.91 \pm \\
3.37\end{array}$ & $\begin{array}{c}* \\
42.63 \pm \\
8.58\end{array}$ & $\begin{array}{c}* \\
36.58 \pm \\
3.34\end{array}$ \\
\hline $\begin{array}{l}\text { VLDL- } \\
\text { Cholesterol } \\
\text { (mg/dl) }\end{array}$ & $\begin{array}{c}5.50 \pm \\
0.61\end{array}$ & $\begin{array}{c}25.80 \pm \\
0.63 \\
x x x\end{array}$ & $\begin{array}{c}* * * \\
5.54 \pm \\
0.60\end{array}$ & $\begin{array}{c}* * \\
6.38 \pm \\
0.44\end{array}$ & $\begin{array}{c}* \\
8.53 \pm \\
1.71\end{array}$ & $\begin{array}{c}* \\
7.31 \pm \\
0.66\end{array}$ \\
\hline
\end{tabular}

$\mathrm{xx}$ and $\mathrm{xxx} \mathrm{P}<0.001$ : Significantly different from normal control group at $\mathrm{xx}=\mathrm{P}<0.01$ and $\mathrm{xxx}=\mathrm{P}<0.001$.

$*$, ** and $* * *$ : Significantly different from ethanol-treated group (B) at $*=\mathrm{P}<0.05$, $* *=\mathrm{P}<0.01$ and $* * * \mathrm{P}<0.001$.

(aa): Significantly different from (Ethanol + Leptin) group at $\mathrm{P}=<0.01$.

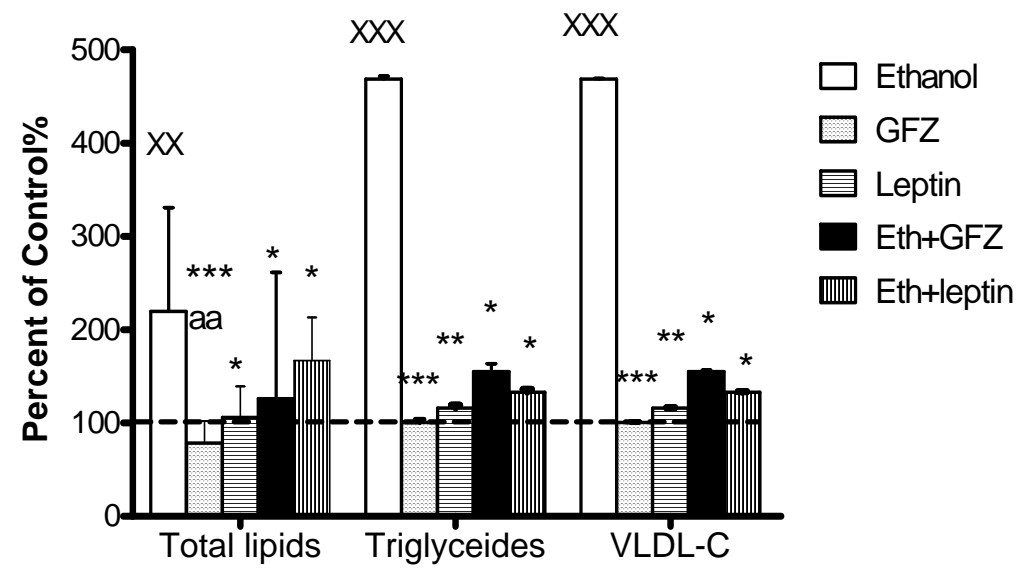

Fig (3): Effect of ethanol and either GFZ or leptin separately or combined with ethanol on liver total lipids, serum triglycerides and VLDL-C of control and experimental rats. 
Table (3): The effect of ethanol, GFZ, leptin hormone or combination of ethanol with either GFZ or leptin hormone on serum level of total cholesterol and serum lipoproteins (HDL-C, LDL-C and LDL-C/HDL-C ratio) (Mean \pm S.E):

\begin{tabular}{|c|c|c|c|c|c|c|}
\hline Group & $\begin{array}{l}\text { Control } \\
\text { Group } \\
\text { (A) }\end{array}$ & $\begin{array}{l}\text { Ethanol } \\
\text { Group } \\
\text { (B) }\end{array}$ & $\begin{array}{c}\text { GFZ } \\
\text { Group } \\
\text { (C) }\end{array}$ & $\begin{array}{l}\text { Leptin } \\
\text { Group } \\
\text { (D) }\end{array}$ & $\begin{array}{c}\text { Eth+GFZ } \\
\text { Group } \\
\text { (E) }\end{array}$ & $\begin{array}{l}\text { Eth+Leptin } \\
\text { Group } \\
\text { (F) }\end{array}$ \\
\hline $\begin{array}{l}\text { Serum Total } \\
\text { Cholesterol } \\
(\mathrm{mg} / \mathrm{dl})\end{array}$ & $\begin{array}{c}68.96 \pm \\
1.58\end{array}$ & $\begin{array}{c}110.79 \pm \\
2.69 \\
x \times x\end{array}$ & $\begin{array}{c}* * * \\
70.91 \pm \\
2.22 \\
\text { (aаa) } \\
\end{array}$ & $\begin{array}{c}* * * \\
71.40 \\
\pm 3.25 \\
\text { (aaa) } \\
\end{array}$ & $\begin{array}{c}* * * \\
73.35 \pm \\
2.91 \\
(\text { aа) }\end{array}$ & $\begin{array}{c}* * * \\
90.01 \pm \\
3.70 \\
x x x\end{array}$ \\
\hline $\begin{array}{l}\text { LDL- C } \\
(\mathrm{mg} / \mathrm{dl})\end{array}$ & $\begin{array}{c}32.62 \pm \\
1.55\end{array}$ & $\begin{array}{c}46.89 \pm \\
2.76 \\
x x \\
\end{array}$ & $\begin{array}{c}* * \\
32.09 \pm \\
1.63\end{array}$ & $\begin{array}{c}* \\
32.30 \pm \\
1.74\end{array}$ & $\begin{array}{c}* \\
34.89 \pm \\
2.63\end{array}$ & $\begin{array}{c}32.62 \pm \\
4.64\end{array}$ \\
\hline $\begin{array}{l}\text { HDL-C } \\
(\mathrm{mg} / \mathrm{dl})\end{array}$ & $\begin{array}{c}33.10 \pm \\
0.70\end{array}$ & $\begin{array}{c}21.45 \pm \\
2.14 \\
\mathrm{xx} \\
\end{array}$ & $\begin{array}{c}30.87 \pm \\
0.78\end{array}$ & $\begin{array}{c}* * * \\
37.31 \pm \\
2.57\end{array}$ & $\begin{array}{c}28.65 \pm \\
0.58 \\
b \\
\end{array}$ & $\begin{array}{c}* * \\
34.03 \pm \\
1.50\end{array}$ \\
\hline $\begin{array}{l}\text { LDL-C } \\
\text { /HDL-C ratio }\end{array}$ & $\begin{array}{c}0.98 \pm \\
0.05\end{array}$ & $\begin{array}{c}2.27 \pm \\
0.13 \\
\mathrm{Xxx} \\
\end{array}$ & $\begin{array}{c}* * \\
1.04 \pm \\
0.06\end{array}$ & $\begin{array}{c}* * * \\
0.93 \pm \\
0.06\end{array}$ & $\begin{array}{c}* \\
1.22 \pm \\
0.11\end{array}$ & $\begin{array}{c}* * \\
0.93 \pm \\
0.12\end{array}$ \\
\hline
\end{tabular}

$\mathrm{xx}$ and $\mathrm{xxx} \mathrm{P}<0.001$ : Significantly different from normal control group at $\mathrm{xx}=\mathrm{P}<0.01$ and $\mathrm{xxx}=\mathrm{P}<0.001$.

$*$, ** and $* * *$ : Significantly different from ethanol-treated group (B) at $*=\mathrm{P}<0.05$, $* *=\mathrm{P}<0.01$ and $* * * \mathrm{P}<0.001$.

(aa) and (aaa): Significantly different from (Ethanol + Leptin) group at aa $=\mathrm{P}<0.01$ and aaa $=\mathrm{P}<0.001$.

(b): Significantly different from (Leptin) group at $\mathrm{P}=<0.05$. 


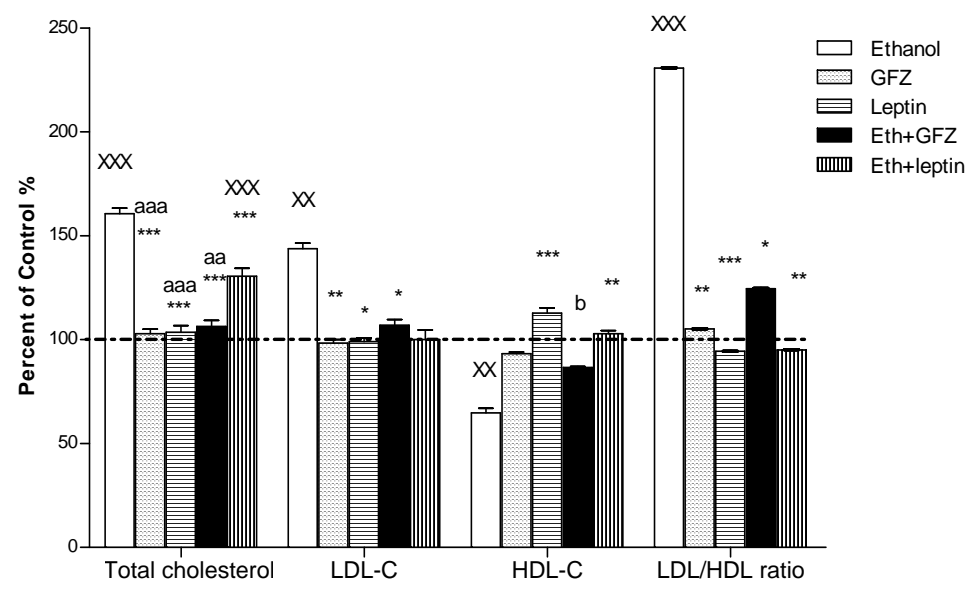

Fig (4): Effect of ethanol and either GFZ or leptin separately or combined with ethanol on serum total cholesterol, LDL-C, HDL-C and LDL-C/HDL-C ratio levels of control and experimental rats. 
Table (4): The effect of ethanol, GFZ, leptin hormone or combination of ethanol with either GFZ or leptin hormone on serum level of total protein, albumin and albumin globulin ratio (A/G ratio) (Mean \pm S.E):

\begin{tabular}{|l|c|c|c|c|c|c|}
\hline \multicolumn{1}{|c|}{ Group } & $\begin{array}{c}\text { Control } \\
\text { Group } \\
\text { (A) }\end{array}$ & $\begin{array}{c}\text { Ethanol } \\
\text { Group } \\
\text { (B) }\end{array}$ & $\begin{array}{c}\text { GFZ } \\
\text { Group } \\
\text { (C) }\end{array}$ & $\begin{array}{c}\text { Leptin } \\
\text { Group } \\
\text { (D) }\end{array}$ & $\begin{array}{c}\text { Eth+GFZ } \\
\text { Group } \\
\text { (E) }\end{array}$ & $\begin{array}{c}\text { Eth+Leptin } \\
\text { Group } \\
\text { (F) }\end{array}$ \\
\hline Serum Total & & & $* * *$ & $* * *$ & & \\
Proteins & $6.78 \pm$ & $5.24 \pm$ & $8.08 \pm$ & $7.35 \pm$ & $6.71 \pm$ & $\mathbf{6 \pm 0 . 2 4}$ \\
(g/dl) & 0.07 & 0.22 & 0.44 & 0.28 & 0.10 & \\
& & & aaa & a & & $*$ \\
Serum & & & $* * *$ & $*$ & & $4.22 \pm$ \\
Albumin & $4.45 \pm$ & $3.45 \pm 0.05$ & $4.61 \pm$ & $4.11 \pm$ & $4.12 \pm$ & $\mathbf{0 . 0 8}$ \\
(g/dl) & 0.07 & $x \times x$ & 0.07 & 0.36 & 0.05 & $\mathbf{2 . 9 7 \pm}$ \\
\hline & $\mathbf{1 . 8 3 \pm}$ & $\mathbf{1 . 9 3} \pm$ & $\mathbf{1 . 4 3} \pm$ & $\mathbf{1 . 4 4} \pm$ & $\mathbf{1 . 6 0 \pm}$ & $\mathbf{0 . 5 6}$ \\
A/G ratio & $\mathbf{0 . 1 0}$ & $\mathbf{0 . 1 8}$ & $\mathbf{0 . 1 0}$ & $\mathbf{0 . 3 0}$ & $\mathbf{0 . 0 5}$ & \\
& & & $\mathbf{a}$ & $\mathbf{a}$ & & \\
\hline
\end{tabular}

$x x x: P<0.001$ : Significantly different from normal control group at $\mathrm{P}=<0.001$.

$*$ and $* * *$ : Significantly different from ethanol-treated group (B) at $*=\mathrm{P}<0.05$ and $* * * \mathrm{P}<0.001$.

(a) and (aaa): Significantly different from (Ethanol + Leptin) group at aa $=\mathrm{P}<0.05$ and $\mathrm{aaa}=\mathrm{P}<0.001$.

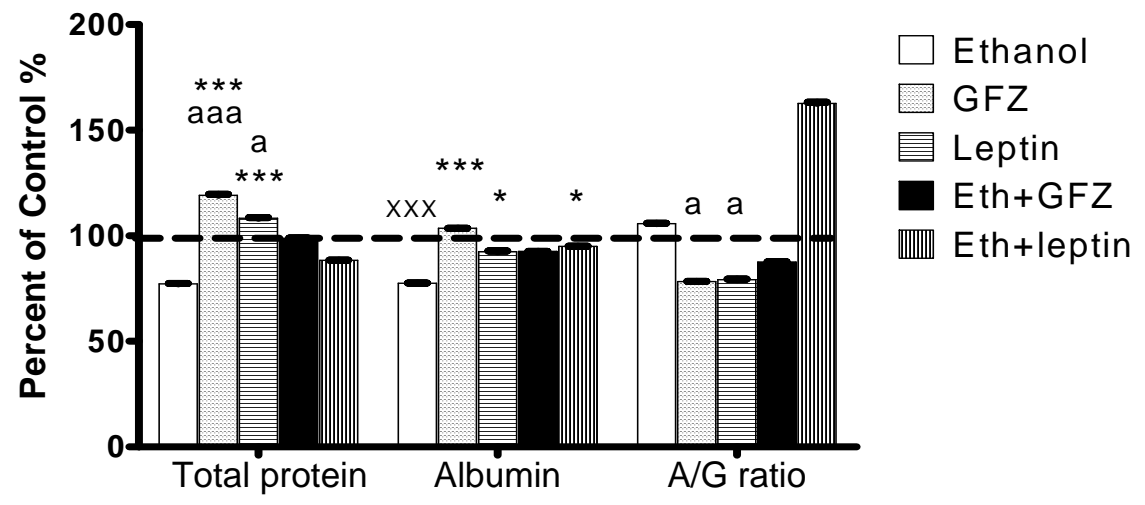

Fig (5): Effect of ethanol and either GFZ or leptin separately or combined with ethanol on serum total protein, serum albumin and $A / G$ ratio levels of control and experimental rats. 
Table (5): The effect of ethanol, GFZ, leptin hormone or combination of ethanol with either GFZ or leptin hormone on serum level of glucose (Mean \pm S.E):

\begin{tabular}{|l|c|c|c|c|c|c|}
\hline \multicolumn{1}{|c|}{ Group } & $\begin{array}{c}\text { Group } \\
\text { (A) } \\
\text { Parameter }\end{array}$ & $\begin{array}{c}\text { Group } \\
\text { (B) } \\
\text { Control }\end{array}$ & $\begin{array}{c}\text { Group } \\
\text { (C) } \\
\text { Ethanol }\end{array}$ & $\begin{array}{c}\text { Group } \\
\text { (D) } \\
\text { Leptin }\end{array}$ & $\begin{array}{c}\text { Group } \\
\text { (E) } \\
\text { Eth+GFZ }\end{array}$ & $\begin{array}{c}\text { Group } \\
\text { (F) } \\
\text { Eth+Leptin }\end{array}$ \\
\hline $\begin{array}{l}\text { Serum level } \\
\text { of glucose }\end{array}$ & $108.45 \pm$ & $97.68 \pm$ & $102.86 \pm$ & $77.08 \pm$ & $84.21 \pm$ & $108.65 \pm$ \\
(mg/dl) & 1.71 & 6.19 & 4.52 & 2.85 & 3.77 & 17.90 \\
& & & b & a & a & \\
\hline
\end{tabular}

**: Significantly different from ethanol-treated group (B) at $\mathrm{P}=<0.01$.

(a): Significantly different from (Ethanol + Leptin) group at $\mathrm{P}=<0.05$.

(b): Significantly different from (Leptin) group at $\mathrm{P}=<0.05$.

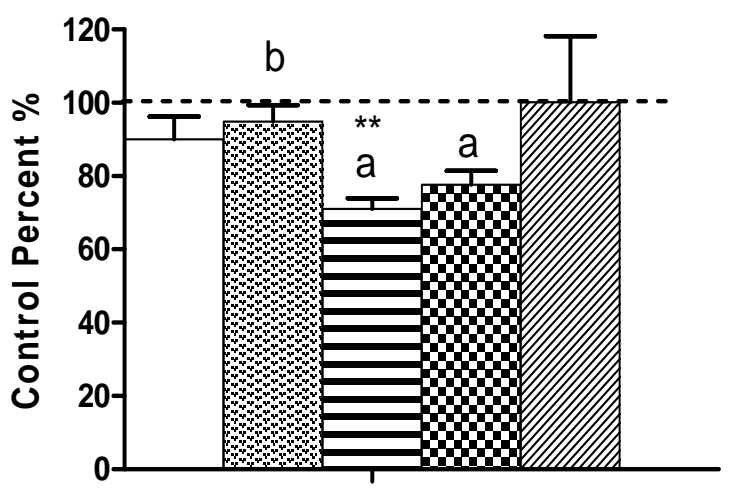

Ethanol

GFZ

$\mathbf{0}$ Leptin

Eth+GFZ

$\Delta \nabla$ Eth+Leptin

Fig (6): Effect of ethanol and either GFZ or leptin separately or combined with ethanol on serum glucose level of control and experimental rats. 
A

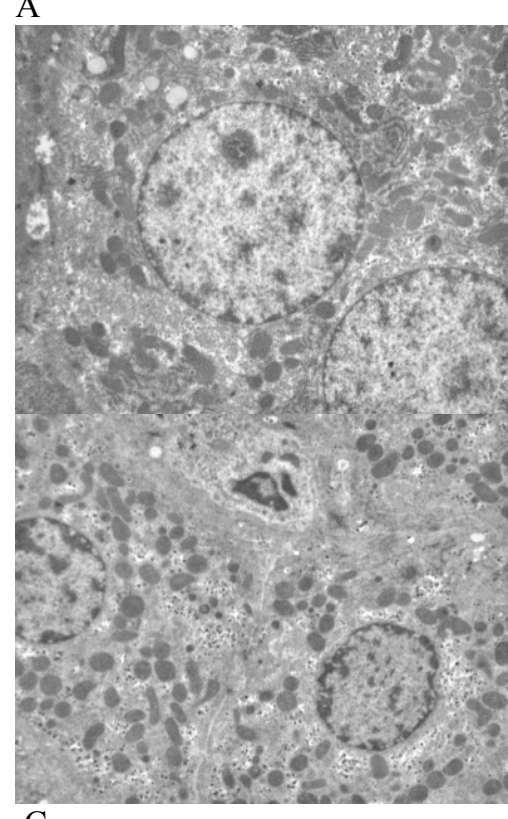

B

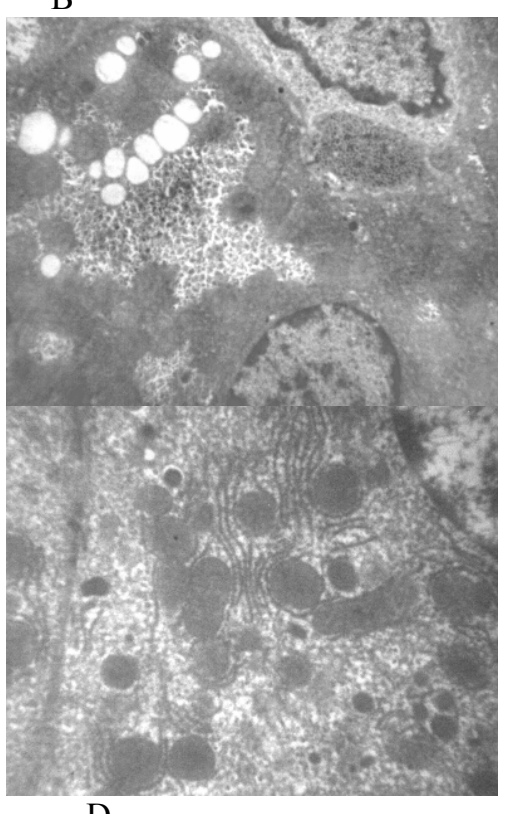

$\mathrm{D}$

Fig(7): Representative photomicrographs of the histopathological changes in the liver of rats after administering ethanol and either GFZ or leptin separately or combined with ethanol (A) Control rat, (B) Ethanol treated rat, (C) GFZ treated rat, (D) Leptin treated rat.

\section{DISCUSSION}

Alcoholism is a major problem in the modern world ${ }^{(33)}$. The World Health Organization (WHO) announced that alcohol consumption is responsible for increasing the risk of liver cirrhosis, certain cancers, raised blood pressure, stroke and congenital malformations ${ }^{(34)}$. Alcohol abuse is now becoming a rising problem in the Middle East due to globalization.

Interaction of ethanol with lipid metabolism is complex. When ethanol is present, it becomes the preferred fuel for the liver and displaces fat as a source of energy, blocking fat oxidation and favoring fat accumulation. The accumulation of fat in the liver on chronic alcohol intake acts as a stimulus for the secretion of lipoproteins into the blood stream and the development of hyperlipidemia ${ }^{(35)}$.

Leptin hormone was discovered in 1994, it is secreted mainly by adipocytes, although expression in placenta, fetal tissue, stomach and other tissues have also been observed. Leptin informs the brain about the size of the fat stores ${ }^{(36)}$, and has a wide variety of central and peripheral actions, including effects on reproduction, lipid metabolism, 
immune system, blood pressure and angiogenesis $^{(37)}$.

In the present study, the difference in weight of rats at the end of the experiment in groups B, D \& F were significantly lower than at the beginning of the experiment. These results agreed with those of Kalaivanisailaja et $\boldsymbol{a l}^{(38)}$ and Balasubramaniyan et al. ${ }^{(39)}$ and this was attributed to alcohol induction to

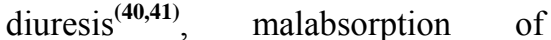
calories $^{(42)}$ and increase in oxygen consumption which may lead to weight loss ${ }^{(43)}$.

Leptin administration alone or mixed with ethanol was shown to prevent further weight gain of the animals $^{(39,44)}$. Investigators have traced the neuronal pathways through which leptin works in the brain and have shown that other hormones involved in weight control, work through the same pathways especially the arcuate nucleus ${ }^{(45)}$. Leptin acts through the arcuate nucleus and increases the expression of cortisol releasing factor (CRF), decreases neuropeptide Y (NPY) and affects the expression of other neuropeptides involved in appetite and energy balance. These effects strongly implicate leptin as a negative feedback signal, which reflects body $\operatorname{adiposity}^{(37)}$.

The present study, ethanol treated group resulted in significant elevation of liver total lipids as compared to normal control group. This finding is consistent with the report of

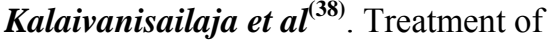
the animals with GFZ or leptin alone or mixed with ethanol resulted in significant reduction of liver total lipids as compared to ethanol induced- hyperlipidemia group. Leptin is known to regulate lipid metabolism both indirectly through the CNS and directly in the peripheral tissues. Both pathways end up with similar outcomes, a decrease in triglycerides (TG) synthesis and increase in lipolytic rates and lipid oxidation. This is achieved by a reduction in calorie intake, causing increased reliance on internal energy stores, mainly TG. Modulation of energy expenditure by leptin through inhibition of metabolic rate, essentially acts to further increase TG use. This shift in metabolism towards a catabolic route coupled with the direct lipolytic and oxidative effects of leptin on peripheral tissues sum together to cause more rapid

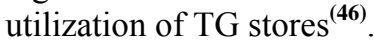

It was reported that GFZ increases liver expression and binding activity of perioxisome proliferatoractivated receptor (PPAR $\alpha)$ and it has been shown PPAR $\alpha$ activity increases liver $\mathrm{X}$ receptor (LXR) expression and the activity of that receptor is directly involved in the control of lipid and glucose metabolism ${ }^{(47)}$.

In the present study, the mean serum levels of total cholesterol (TC) and TG were elevated significantly in ethanol treated group in agreement with Balasubramaniyan et al ${ }^{(44)}$.

The increased intracellular accumulation of TG in the presence of ethanol is due to increased fatty acid uptake, decreased fatty acid oxidation in the citric acid cycle (TCA) and decreased lipoprotein secretion and decreased activity of lipoproteinlipase $^{(48)}$.

Administering leptin alone or mixed with ethanol markedly reduced 
both TC and TG. This in consistent with Kalaivanisailaja et al (38) and Balasubramaniyan et al. ${ }^{(39,44)}$.

Cohen et al ${ }^{(49)}$ demonstrated that leptin may attenuate insulin activity in isolated hepatocytes. This may explain the cause for the normalization of serum TC level observed in leptin-treated mice. However, reduction in lipogenesis, decreased tissue TG content and decreased glucose oxidation are consistent with the hypothesis that leptin modulates energy homeostasis by directing lipids away from storage to oxidation, as suggested by in vitro studies ${ }^{\mathbf{( 5 0 )}}$. The TG content of islets is an important modulator of insulin secretion (51) and leptin has been shown to deplete islets TG content ${ }^{(52)}$ and increase the expression of the enzymes involved in fatty acid oxidation $^{(53)}$.

GFZ was found to lower plasma TG level in patients and animal models (54) through its effect on PPAR $\alpha$. PPAR $\alpha$ mediates regulation of several genes involved in metabolism of triglycerides rich lipoprotein. This may in turn lead to: increased lipoprotein lipase (LPL) mediated lipolysis and lowered hepatic apoliprotein C-III synthesis (55)

In the present study ethanolinduced hyperlipidemia group showed significant reduction in high density lipoproteins (HDL-C) serum level and at the same time significant elevation in low density lipoproteins (LDL-C), very low density lipoproteins (VLDLC) serum levels and LDL-C/HDL-C ratio as compared to normal control group. Ethanol consumption leads to increased concentrations of plasma
LDL-C and VLDL-C, as the release of these lipoproteins from the liver apparently does not keep pace with the rate of formation of $\mathrm{TG}$ which accumulates in the liver in addition to decrease in activity of LPL ${ }^{(56)}$. The lowered HDL-C levels in mice could be attributed to decreased plasma LPL and lecithin cholesterol acyl transferase (LCAT) activities in these mice ${ }^{(38)}$.

Silver et al ${ }^{(57)}$ demonstrated that hepatocytes of ob/ob mice (mutant leptin gene) had reduced binding, association, degradation, recycling and resecretion of HDL apoproteins and this defect in the liver catabolism of HDL was reversed by low-dose of leptin treatment.

In the current study, leptin administration alone or mixed with ethanol showed marked improvement in HDL-C, LDL-C, VLDL-C and LDL-C/HDL-C ratio compared to ethanol treated rats. Leptin administration resulted in the optimum activity of plasma LPL which may lead to decrease in LDL-C and VLDL-C levels ${ }^{(38)}$.

In the current study, the mean values of serum glucose level of all groups were lower but not significantly than that of control group. Treatment of leptin alone showed significant reduction in serum glucose level as compared to ethanolinduced hyperlipidemia group.

Low-dose leptin treatment ameliorates insulin resistance and hyperlipidemia in patients with low leptin levels resulting from congenital or acquired lipodystrophy ${ }^{(58)}$. Metabolically, leptin promotes the redistribution of intrahepatic glucose fluxes with an increase in 
gluconeogenesis and a parallel decrease in glycogenolysis ${ }^{(59,60)}$. It was confirmed that leptin causes an improvement in skeletal muscle insulin sensitivity by both peripheral and central effect ${ }^{(61)}$ that fully agrees with the present results.

In contrast to the current results, some studies reported that leptin inhibits insulin gene transcription ${ }^{(62,63)}$ and insulin secretion ${ }^{(64,65)}$.

Leptin can inhibit insulin secretion by activating ATPdependent potassium channels or via interactions with the cAMP protein kinase A signaling pathway ${ }^{(66)}$, perhaps by activating phosphodiesterase $\mathrm{B}_{3}{ }^{(67)}$.

Dumont et al ${ }^{(68)}$ suggested that insulin resistance may not be improved without major variation in plasma TG levels nor in body fatness and glucose level in GFZ treated rats. On the other hand, Steiner ${ }^{(69)}$ had already reported improved insulin sensitivity in non-diabetic subjects treated with GFZ.

In the present study administering leptin to ethanol-administered rats significantly reduced the fatty changes and improved liver tissue histology which is agreed with the results of Kalaivanisailaja et al. ${ }^{(38)}$. Acetaldehyde formed by the enzymatic oxidation of alcohol in the liver is thought to play a major role in the development of cell damage from alcohol. It may combine covalently with cell membrane proteins causing membrane damage. It may, also, damage hepatic microtubules by interfering with the liver proteins and promoting collagen formation and, also, damage hepatic mitochondria ${ }^{(70)}$. Administering leptin to ethanol administered rats significantly reduced the fatty changes and improved liver tissue histology which proves that elevated systemic leptin levels can attenuate accumulation of fat in the liver, preventing lipoapoptosis and our results are fully agreed with Kalaivanisailaja et al ${ }^{(38)}$.

\section{CONCLUSION}

In conclusion, the findings of the present study indicated that intraperitoneal injection of leptin hormone was more effective as compared to GFZ in preventing the rise in lipids and lipoproteins concentrations significantly in an animal model of alcohol induced hyperlipidemia

Moreover, the histopathological examinations revealed that leptin treatment had more protective effects on rat's liver in comparison to GFZ treatment.

\section{REFERENCES}

1. Campfield LA, Smith FJ,Guisez Y, Devos $R$ and Burn PR (1995). Recombinant mouse OB protein: evidence for a peripheral signal linking adiposity and central neural networks. Science 269: 546-549.

2. Frühbeck $\mathbf{G}$ and Salvador $\mathbf{J}$ (2000). Relation between leptin and the regulation of glucose metabolism. Diabetologia 43: 312.

3. Shepherd J, Griffin B, Caslake M, Gaw A and Packard C (1991). The influence of fibrates on lipoprotein metabolism. Atherosclerosis Rev., 22:163-169. 
4. Todd PA and Ward A (1988). Gemfibrozil. A review of its pharmacodynamic and pharmacokinetic properties, and therapeutic use in dyslipidaemia. Drugs 36:314-339.

5. Backes JM, Gibson CA, Ruisinger JF and Moriarty PM (2007). Fibrates what have we learned in the past 40 years? Pharmacotherapy. (3):412-24.

6. Simsolo RB, Ong JM and Kem PA (1993). Effect of gemfibrozil on adipose tissues and muscle lipoprotein lipase. Metabolism 42:1486-1491.

7. Avogaro $\mathbf{P}$ and Cazzolatu $\mathbf{G}$ (1975). Changes in the composition and physiochemical characteristics of serum lipoproteins during ethanol induced lipidemia in alcoholic subjects. Metab. Clin. Exp. 219:1231 -42.

8. Hirayama C, Nosaka Y, Yamada $S$ and Yamanishi $Y$ (1979). Effect of chronic ethanol administration on serum highdensity lipoprotein cholesterol in rats. Res. Commun. Chem. Pathol. Pharmacol., 26:563-9.

9. Baraona $E$ and Lieber CS (1979). Effects of ethanol on lipid metabolism. J. Lipid Res., 20:289-315.

10. Baraona E, Sanolainen $M$, Karrenty C, Leo Maria A and Lieber CS (1983). Pathogenesis of alcoholic hypertriglyceridemia. Trans. Assoc. Am. Physicians 96:306-15.

11. Allain CC, Poon LS, Chan CSG and Richmond W (1974). Enzymatic determination of total serum cholesterol. Clin. Chem.,20/4 ,470.

12. Vassault A, Grafmeyer $D$ and Naudin (1986). Protocole de validation de techniques. Document B, Stade 3 Ann. Biol. Clin., 44,686.

13. Fossati $P$ and Prencipe $L$ (1982). Serum triglycerides determined colormetrically with an enzyme that produces hydrogen peroxide. Clin. Chem., 28:2077-80.

14. Castelli WP (1986). The triglyceride issue: A view from Framingham. Amer. Heart 112 (2) J.p:432-437.

15. Wieland $H$ and Seidel UD (1983). J. Lipid Res. 24,904. Martin et al: Lancet 1986/II: P.933-936.

16. Schaefer EJ and McNamara $J$ (1997). Overview of the diagnosis and treatment of lipid disorders. In: Rifai N, Wamick GR, Dominiczak MH, eds. Handbook of lipoprotein testing. Washington: AACC Press: 25-48.

17. Rifai N, Bachorik PS and Albers JJ (1999). Lipids, lipoproteins and apolipoproteins.In: Burtis CA, Ashwood ER, editors. Tietz Textbook of Clinical Chemistry. $3^{\text {rd }}$ ed. Philadelphia: W.B. Saunders company: 809-61.

18. Burstein M, Scholnick HR and Morfin R (1970). Rapid method for the isolation of lipoproteins from human serum by precipitation with polyanions, $\mathrm{J}$ of Lipid Res, 11(6):583-95.

19. Lopes-Virella MF (1977). Clin.Chem 882. 
20. Fruchart JC (1982). Rev.Fr.des laboratories, 103.

21. Weichselbaum PE (1946). An accurate and rapid method for the determination of proteins in small amounts of blood serum and plasma. Am. J.Path:16-40.

22. Gornall A, Fleury $P$ and Eberhard $R \quad$ (1951). Determination of proteins by photometric, biuret method, according to the technique of Gornall. Ann Biol Clin (Paris).9(10-11-12):453-66.

23. Johnson $\mathbf{R}$ and Silveman $\mathbf{L M}$ (2001). Proteins, in Tietz Fundamentals of Clinical Chemistry, 5th edition, (W.B. Saunders eds. Philadelphia USA):325.

24. Doumas B, Watson W, Ard and Biggs HG (1971).Albumin standards and the measurement of serum albumin with bromocresol green. Clin Chim.Acta:31-87.

25. Doumas BT and Biggs HG (1972). Determination of serum albumin; 'Standard Methods of Clinical Chemistry'. Acad. Press N.Y.:7-175.

26. Drupt F (1974).Dosage de l'albumine seique par le vert de bromocresol Pharm.Biol:9-777.

27. Trinder $P$ (1969). Determination of glucose in blood using glucose oxidase with an alternative oxygen acceptor. Ann.clin Biochem 624

28. Burrin JM and Price CP (1985). Measurement of blood glucose. Ann. Clin. Biochem, 22327.

29. Thomas L (1998). Clinical laboratory Diagnostics. $1^{\text {st }}$ ed. Frankfurt: TH-Books p.131-7.
30. Sacks DB (2001). Carbohydrates, in Tietz fundamentals of clinical chemistry, 5th edition, (W.B. Saunders eds. Philadelphia USA, 427.

31. Zöliner $\mathbf{N}$ and Kirsch $K$ (1962).Z.ges.exp.Med 135,545.

32. Po AL (1998). In (Statistics for pharmacists) Chapter 11. PP.180185.

33. Jernigan DH (2001). Global Status Report: Alcohol and Young People. Geneva, WHO.

34. Lieber CS (1993). Alcoholic liver disease: a public health issue in need of a public health approach. Semin. Liver Disease 13: 105-107.

35. Leiber CS and Schmid $R$. (1961). The effect of ethanol on fatty acid metabolism: stimulation of hepatic fatty acid synthesis in vitro. J. Clin. Invest., 40:394-9.

36. Fruhbeck G, Ambrosi JG and Salvador J (2001). Leptininduced lipolysis opposes the tonic inhibition of endogenous adenosine in white adipocytes. FASEB J., 15:333- 40.

37. Shannon PR and Jean MW (2000). Leptin: an essential regulator of lipid metabolism. Comp. Biochem. Physiol., 125:285- 97.

38. Kalaivanisailaja J, Vaiyapuri Manju and Namasivayam Nalini (2003). Lipid profile in mice fed a high-fat diet after exogenous leptin administration. Pol. J. Pharmacol., 55: 763-769.

39. Balasubramaniyan $\mathrm{V}$ and Nalini N (2006). Intraperitoneal leptin regulates lipid metabolism in ethanol supplemented Mus 
musculas heart.Life Science 78 :831 - 837 .

40. Rubini ME, $C$ R Kluman and E. Lamdin (1955). Studies on alcohol diuresis. The effect of ethyl alcohol ingestion on water, electrolyte, and acid-base metabolism. J. Clin. Invest., 34: 439-447.

41. Ogata M, JH Mendelson, and NK Mello (1968). Electrolytes and osmolality in alcoholics during experimentally induced intoxication. Psychosom. Med., 30:453-488.

42. Frederick $A$ and MD Klipstein (1970). Recent advances in tropical malabsorption. Scand. J. Gastroenterol. 5, (suppl.6): 93114.

43. Israel $Y$, L. Videla and $J$. Bernstein (1975). Liver hypermetabolic state after chronic ethanol consumption: hormonal interrelations and pathogenic implications. Federation PYOC3., 4: 2052-2059.

44. Balasubramaniyan V. and Nalini $N$ (2003). The Potential beneficial effect of leptin on an experimental model of hyperlipidemia induced by chronic ethanol treatment. Clinica Chimica Acta 337: 85-91.

45. Marx J (2003). Cellular warriors at the battle of the bulge. Science 299:846-9.

46. Reidy SP and Weber J (2000). Leptin: an essential regulator of lipid metabolism. Comp. Biochem. Physiol., Part A 125: 285-298.

47. Mandard S, Muller $M$ and Kersten S (2004). Peroxisome proliferator activated receptor a target genes. Cell. Mol. Life Sci. 61, 393-416.

48. Grunnet $\mathbf{N}$ and Kondrup $\mathbf{J}$ (1985). Effects of ethanol on lipid metabolismin cultured hepatocytes. Biochem J., 228:673-81.

49. Cohen B, Novick D and Rubenstein M (1996). Modulation of insulin activities by leptin. Science 274:1185-8.

50. Muller GJ, Ertl J, Gerl EM and Preibisch G (1997). Leptin impairs metabolic actions of insulin in isolated rat adipocytes. J. Biol. Chem., 272:10585-93.

51. Klein KO, Martha PMJ, Blizzard RM, Herbst $T$ and Rogol AD (1996). A longitudinal assessment of hormonal and physical alterations during normal puberty in boys. II. Estrogen levels as determined by an ultrasensitive bioassay. J. Clin. Endocrinol. Metab., 81:3203-7.

52. Rossetti L, Massillon D, Barzilai N,Vuguin P, Chen W and Hawkins M(1997). Short term effects of leptin on hepatic gluconeogenesis and in vivo insulin action. J. Biol. Chem., 272:27758-27763.

53. Zhou YT, Shimabukuro M, Koyama K (1997). Induction by leptin of uncoupling protein-2 and enzymes of fatty acid oxidation. Proc. Natl. Acad. Sci. 94:6386-90.

54. Haubewallner S, Essenburg AD, Barnett BC, Pape ME, De Mattos RB, Krause BR, Minton LL, Aurebach BJ, Newton RS, Leff $T$ and Bisgaier CL (1995). Hypolipidemic activity of selective fibrates correlates to 
changes in hepatic apolipoprotein C-Ш expression: A potential physiology basis for their model of action. J- Lipid Res., 36: 25412551.

55. Fruchart JC, Brewer $\mathrm{HB}$ and Leitersdorf E (1998). Consensus fot the use of fibrates in the treatment of dyslipoproteinemia and coronary heart disease. Am. J. Cardiol., 81:912-916.

56. David WC and Lawrence $L$ (1988). Metabolism of alcohol and the pathophysiology of alcoholic liver disease. Principles and practices of gastroenterology and hepatology. New York: Elsevier. p. 1103-20.

57. Silver DL, Wang $N$ and Tall AR (2000). Defective HDL particle uptake in ob/ob hepatocytes causes decreased recycling, degradation and selective lipid uptake. J. Clin. Invest., 105: 151159.

58. Oral EA, Simha V, Ruiz E, Andewelt A, Premkumar A, Snell P, Wagner AJ, DePaoli AM, Reitman ML, Taylor SI, Gorden $P$ and Garg $A(2002)$. Leptin-replacement therapy for lipodystrophy. N. Engl. J. Med., 346:570-578.

59. Kamohara S, Burcelin R, Halaas JL, Friedman JM and Charron MJ (1997). Acute stimulation of glucose metabolism in mice by leptin treatment. Nature 389: 374-377.

60. Friedman JM (2002). The function of leptin in nutrition, weight and physiology. Nutrition Reviews 60 :S1-S14.

61. Minokoshi Y, Kim YB, Peroni OD, Fryer LG, Muller $C$ and
Carling D (2002). Leptin stimulates fatty-acid oxidation by activating AMP-activated protein kinase. Nature 415: 339-343.

62. Seufert J, Kieffer $T J$ and Habener JF (1999). Leptin inhibits insulin gene transcription and reverses hyperinsulinemia in leptin-deficient ob/ob mice. Proc. Natl. Acad. Sci. USA 96:674679.

63. Melloul D, Marshak $S$ and Cerasi E (2002). Regulation of insulin gene transcription. Diabetologia 45:309-326.

64. Kieffer TJ and Habener JF (2000). The adipoinsular axis: effects of leptin on pancreatic beta-cells. Am. J. Physiol. Endocrinol. Metab., 278:E1-E14.

65. Margetic S, Gazzola C, Pegg GG and Hill RA (2002) .Leptin: a review of its peripheral actions and interactions. International Journal of Obesity 26: 14071433.

66. Ahren B and Havel PJ (1999). Leptin inhibits insulin secretion induced by cellular cAMP in a pancreatic B cell line (INS-1 cells). Am. J. Physiol., 277:R959-R 966.

67. Zhao AZ, Bornfeldt $\mathrm{KE}$ and Beavo JA (1998). Leptin inhibits insulin secretion by activation of phosphodiesterase 3B. J. Clin. Invest., 102:869-873.

68. Dumont $M$, Mauriège1 $P$, Bergeron J, Després JP and Prud'homme D (2001). Effect of a six month gemfibrozil treatment and dietary recommendations on the metabolic risk profile of visceral obese men. International Journal of Obesity 25:1136-1143. 
69. Steiner G (1991). Altering triglyceride concentrations changes insulin-glucose relationships hypertriglyceridemic patients. Double-blind study with gemfibrozil with implications for atherosclerosis. Diabetes Care 14: 1077-1081.

70. Williams $D$ and Marks V (1995): Scientific Foundations of Biochemistry in Clinical Practice. Second edition.

\title{
دراسة مقارنة حول تأثير هرمون الليتين و جيمفيبروزيل في الفئران المستحدث بها زيادة في الدهون بكحول الأيثيل
}

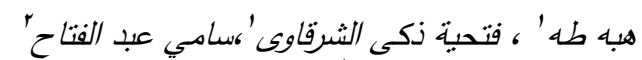

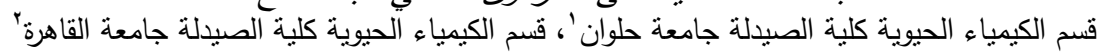

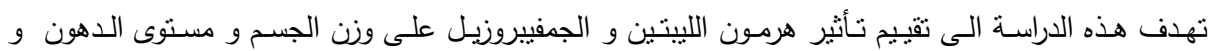

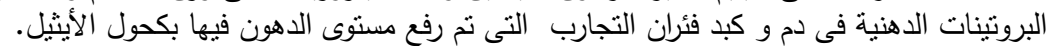

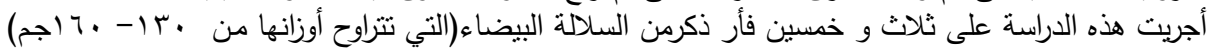

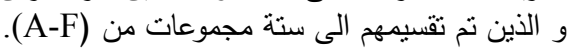

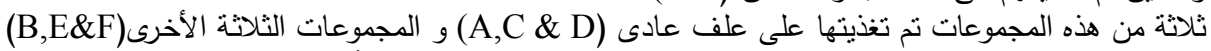

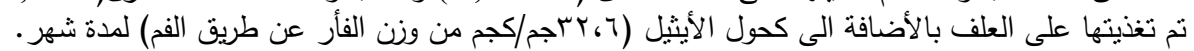

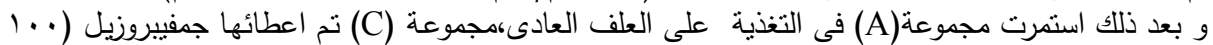

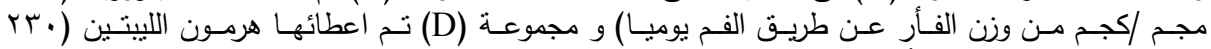

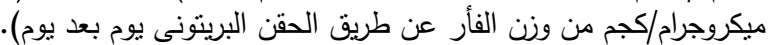

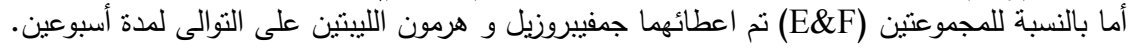

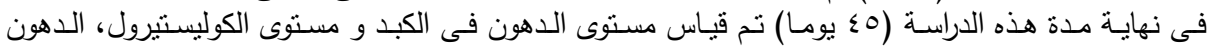

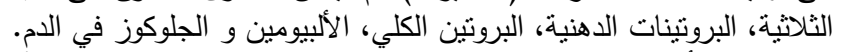

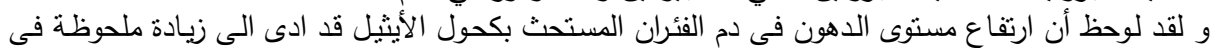

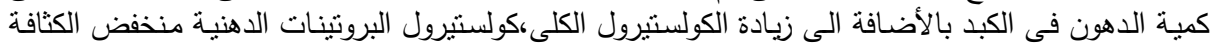

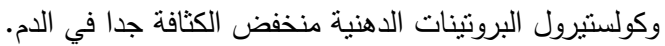

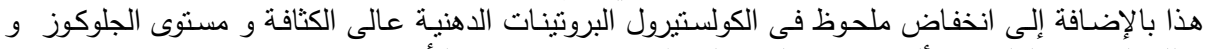

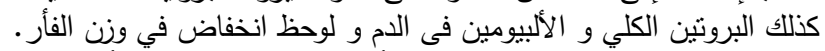

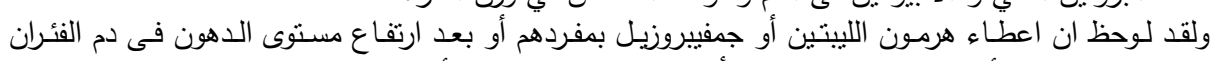

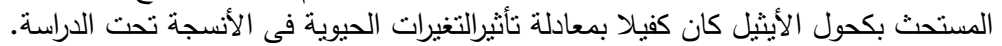

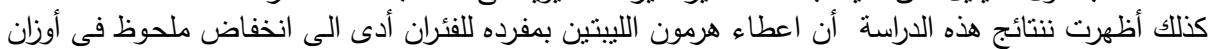

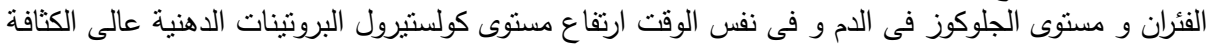

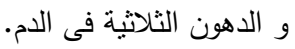

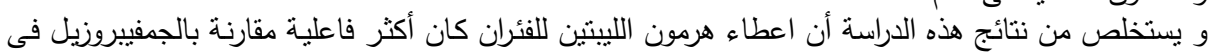

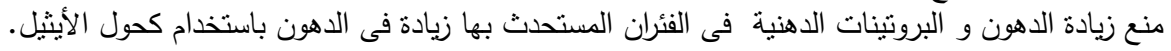

